\title{
UPAYA PENYESUAIAN DIRI MANTAN NARAPIDANA DALAM MENANGGAPI STIGMA NEGATIF DI KECAMATAN KLAKAH, LUMAJANG
}

\author{
${ }^{1}$ Wanda Fristian, ${ }^{2}$ Vina Salvina Darvina. S, ${ }^{3}$ Sulismadi \\ ${ }^{1}$ Universitas Muhammadiyah Malang, Indonesia \\ ${ }^{23}$ Soiologi Universitas Muhammadiyah Malang, Indonesia \\ E-mail: wandafristian14@gmail.com
}

\begin{abstract}
Humans are creatures created by the creator who have a social nature that will always need help from others to interact with each other. This study aims to determine the efforts of adjusting ex-convicts in the community in response to negative stigma. Examining the adjustment efforts of this exconvict uses the Looking Glass Self Theory from C.H.Cooley and the Stigma Theory from Erving Goffman. This research uses a case study approach in qualitative research. Research subjects were ex-convicts who were selected using apurposive technique. The study was conducted in Klakah District, Lumajang Regency with data collection techniques in the form of observation, interviews and documentation. Data analysis techniques using models from Miles and Huberman. Data validity test is done by the source triangulation method. The results of the research conducted by the author are the adjustment efforts made by ex-convicts to be able to return to the community environment will lead to positive and negative results, although it is difficult and requires a long time but the former drug can be accepted back by the community.
\end{abstract}

\author{
Keywords: \\ self-adjustment, former prisoners
}

\begin{abstract}
Abstrak
Manusia adalah makhluk yang diciptakan oleh sang pencipta yang memiliki sifat sosial yang akan selalu membutuhkan bantuan dari orang lain untuk saling berinteraksi satu sama lain. Penelitian ini bertujuan untuk mengetahui upaya penyesuaian diri mantan narapidana dimasyarakat dalam menanggapi stigma negatif. Mengkaji upaya penyesuaian diri mantan narapidana ini menggunakan Teori Looking Glass Self dari C.H.Cooley dan Teori Stigma dari Erving Goffman. Penelitian ini menggunakan pendekatan studi kasus dalam penelitian kualitatif. Subjek penelitian adalah mantan narapidana yang dipilih menggunakan dengan teknik purposive. Penelitian dilakukan di Kecamatan Klakah, Kabupaten Lumajang dengan teknik pengumpulan data berupa observasi, wawancara
\end{abstract}


dan dokumentasi. Teknik analisis data menggunakan model dari Miles and Huberman. Uji keabsahan data dilakukan dengan metode triangulasi sumber. Hasil penelitian yang dilakukan oleh penulis adalah upaya penyesuaian yang dilakukan oleh mantan narapidana untuk dapat kembali di lingkungan masyarakat akan mengarah pada hasil positif dan negatif, walaupun sulit dan membutuhkan waktu yang lama tetapi mantan napi dapat diterima kembali oleh masyarakat.

\section{Kata-kata Kunci: \\ penyesuaian diri, mantan narapidana}

\section{Pendahuluan}

Manusia adalah makhluk yang diciptakan oleh sang pencipta yang memiliki sifat sosial yang akan selalu memerlukan bantuan dari orang lain untuk saling berinteraksi satu sama lain. Terkadang manusia itu sendiri melakukan suatu tindakan yang melanggar norma yang ada di masyarakat yang akan membuat dirinya mendekam di jeruji besi dalam waktu yang sudah ditentukan sebagai hukum atau sanksi karena ia sudah melakukan suatu tindakan yang melanggar aturan yang ada di masyarakat. Mereka terkadang melakukan suatu tindakan tersebut karena berbagai faktor yang mendorongnya melakukan tindakan yang melanggar norma yang ada di dalam masyarakat. Setelah individu melakukan sidang di pengadilan maka individu tersebut sebagai narapidana yang akan menjali kehidupan seharihari di Lembaga Permasyarakatan. Lembaga permasyarakatan yang sering disebut dengan lapas memiliki tujuan sebagai tempat dimana untuk individu atau seseorang yang melakukan kesalahan untuk membenahi diri dengan belajar sedikit demi sedikit untuk dapat bersosialisasi dengan maksud untuk mempersiapkan diri secara fisik ataupun secara mental untuk kembali lagi ke masyarakat dengan perilaku yang baik.

Seseorang narapidana sewaktu dalam jeruji besi mengharapkan cepat untuk bisa menghirup udara luar. Setelah narapidana melakukan hukuman yang diberikan oleh majelis hakim dengan waktu yang sudah di tentukan, narapidana akan dikembalikan ke lingkungan masyarakat dan kembali berkumpul dengan sanak saudara serta dapat kembali berinteraksi dengan masyarakat sekitar. Menyandang predikat sebagai mantan narapidana merupakan beban tersendiri yang akan dipikul oleh seorang mantan narapidana. Hal tersebut karena adanya stigma negatif yang muncul dari masyarakat yang membuat orang-orang dengan status mantan 
narapidana harus bisa beradaptasi lagi dan memiliki kekuatan untuk bertahan dari kesulitan dan hambatan dalam kehidupan sosial. Ironisnya, tidak sedikit orang di masyarakat peduli dengan keberadaan mantan narapidana atau mengakui keberadaan mereka dalam hubungan sosial.

Ada stigma negatif tentang mantan narapidana karena ada banyak napi yang selalu kembali mengulangi kesalahan yang sama seperti yang dia lakukan sebelumnya, sehingga membuat masyarakat pada umumnya memandang rendah mereka dan negatif, tetapi di samping pandangan negatif dari masyarakat, mantan napi sendiri ada juga rasa inferioritas dan juga hambatan psikologis untuk terjun di tengah-tengah masyarakat lagi setelah keluar dari jeruji1. Dengan stigma yang muncul di lingkungan masyarakat, mantan narapidana berupaya menyesuaikan diri dengan lingkungannya. Kebanyakan orang menganggap bahwa narapidana dianggap sebagai pembuat masalah sehingga kebanyakan orang melakukan penolakan dan seringkali mendiskriminasi mantan narapidana. Masyarakat menyoroti dari perspektif negatif semua bentuk perilaku dan kegiatan sehari-hari dari mantan narapidana yang telah dibebaskan dari tahanan, sehingga mantan narapidana merasa dikucilkan atau diasingkan dari komunitas. Kesulitan yang dialami oleh mantan narapidana untuk mendapatkan kembali kepercayaan kecil dari masyarakat sekitar dan kesulitan untuk dapat menemukan pekerjaan untuk memenuhi kebutuhan sehari-hari mereka, baik untuk diri mereka sendiri atau keluarga mereka.

Memiliki suatu kehidupan yang harmonis dan dapat bisa berhubungan baik dengan seluruh lapisan masyarakat di lingkungan dimana ia tinggal merupakan dambaan bagi setiap orang terutama bagi seorang mantan narapidana. Hal tersebut sangat didambakan karena sejatinya sebagai makhluk sosial, seorang mantan narapidana juga membutuhkan pengakuan atas keberadaannya di tengah-tengah masyarakat tempat ia tinggal. Oleh karena itu, adanya suatu proses upaya penyesuaian diri yang baik di dalam lingkungan masyarakat itulah yang nantinya akan bisa mengubah stigma negatif yang diperoleh oleh mantan narapidana di dalam lingkungan. Penelitian tentang upaya penyesuaian diri mantan narapidana di masyarakat dalam menghadapi stigma negatif diharapkan

1 Abraham Barkah Iskandar, Resiliensi Mantan Narapidana Terhadap Penolakan Lingkungan, (Skripsi Program Studi Psikologi Fakultas Psikologi Universitas Sanata Dharma Yogyakarta, 2017), hlm.18. 
dapat memberikan wacana baru untuk masalah sosiologis kehidupan mantan narapidana. Penelitian ini penting untuk mengetahui bagaimana upaya penyesuaian mantan narapidana dalam menghadapi stigma negatif masyarakat yang timbul di tempat tinggal mantan narapidana di Kecamatan Klakah, Kabupaten Lumajang.

\section{Metode Penelitian}

Pendekatan yang peneliti gunakan adalah metode pendekatan studi kasus dengan jenis penelitian kualitatif. Penelitian kualitatif adalah mengamati orang di dalam lingkungannya, dapat berinteraksi dengan mereka dan menafsirkan pendapat mereka tentang dunia sekitar². Metode kualitatif ini digunakan untuk mengungkap dan memahami sesuatu di balik suatu fenomena atau peristiwa yang belum diketahui publik $^{3}$. Studi kasus adalah proses pengumpulan datadan informasi secara mendalam, terperinci, intensif, holistik, dan sistematis tentang seseorang4. Dalam studi kasus ini peneliti mengumpulkan data mengenai diri subjek dari keadaan masa sebelumnya, masa sekarang, dan lingkungan sekitar5.

Peneliti bertujuan untuk menganalisa permasalahan yang ada di Kecamatan Klakah, Kabupaten Lumajang mengenai upaya penyesuaian diri yang dilakukan oleh mantan narapidana menggunakan analisa mikro. Lokasi yang dipilih oleh peneliti adalah di Kecamatan Klakah yang berada di Kabupaten Lumajang. Penelitian ini menggunakan teknik pengumpulan data sumber data primer dan sekunder, yaitu: Sumber data primer merupakan data pokok yang diperoleh secarah langsung melalui observasi dan wawancara. Dalam penelitian ini, peneliti menggunakan wawancara tidak terstruktur (unstructured interview). Wawancara tidak terstruktur (unstructured interview) adalah wawancara yang bebas dimana peneliti tidak menggunakan pedoman wawancara yang telah tersusun secara sistematis dan lengkap untuk pengumpulan data-

2 Nasution. S, Metode Penelitian Naturalistik Kualitatif, (Bandung: PT Tarsito, 1996), hlm.5

3 Anselm Straauss dan Imam Muttaqien, Dasar-dasar Penelitian Kualitatif, (Yogyakarta: Pustaka Pelajar, 2007), hlm.5

4 A. Muri Yusuf, Metode Penelitian: Kuantitatif, Kualitatif, dan Penelitian Gabungan, (Jakarta: Prenamedia Group, 2014), hlm.328.

${ }^{5}$ Imam Gunawan, Metode Penelitian Kualitatif: Teori dan Pratik, (Jakarta: Bumi Aksara, 2013), hlm.116. 
nya. Pedoman wawancara yang digunakan hanya berupa garis-garis besar permasalahan yang akan ditanyakan6.

Data primer ini diambil dari para mantan narapidana yang ada di Kecamatan Klakah, Kabupaten Lumajang. Sumber data sekunder merupakan data tambahan. Data ini diperoleh dari web site, jurnal foto, arsip dan dokumentasi. Dokumentasi adalah mencari data tentang hal-hal atau variabel dalam bentuk catatan, transkrip, buku, koran, majalah, prasasti, notulen, rapat, agenda, dan sebagainya7 ${ }^{7}$. Subjek penelitian ini ditemukan dengan memilih subjek untuk menjadi subjek dalam pengumpulan data lapangan ${ }^{8}$. Teknik penentuan subjek dalam penelitian ini menggunakan teknik purposive. Purposive adalah teknik pengambilan subjek dari sumber data dengan pertimbangan tertentu ${ }^{9}$. Teknik analisis data adalah sama dengan halnya menguraikan kembali data, menjelaskan data sehingga data tersebut pada akhirnya akan dapat ditarik kesimpulan ${ }^{10}$. Teknik analisa data yang digunakan dalam penelitian ini adalah model analisa interaktif yang dikemukakan oleh Miles dan Huberman melalui tiga tahap, yaitu reduksi data (data reduction), penyajian data (data display), dan penarikan kesimpulan (conclusion drawing). Uji validitas data pada penelitian ini menggunakan triangulasi. Peneliti menggunakan triangulasi sumber.

\section{Hasil dan Pembahasan}

Sebagaimana judul yaitu upaya penyesuaian diri mantan narapidana di lingkungan masyarakat dalam menanggapi stigma negatif di Kecamatan Klakah, Kabupaten Lumajang disini peneliti akan menjabarkan hasil pengumpulan data. Hasil dari penelitian maka akan dapat memfokuskan terhadap satu Kecamatan Klakah tersebut. Subjek di penelitian ini menggunakan nama samaran demi etika dari penelitian. Dari hasil penelitian yang sesuai dengan kriteria di temukan sebanyak 5 orang.

${ }^{6}$ Sugiyono, Metode Penelitian Kuantitatif Kualitatif dan R\&D, (Bandung: Alfabeta, 2015), hlm.233-234.

7 Suharsimi Arikunto, Prosedur Penelitian Suatu Pendekatan Praktik, (Jakarta: PT Rineka Cipta, 2010), hlm.206.

8 Sukardi, Penelitian Subjek Penelitian, (Yogyakarta: Lembaga Penelitian IKIP Yogyakarta, 1995), hlm.7-8.

${ }^{9}$ Sugiyono, Metode Penelitian Kuantitatif Kualitatif dan R\&D, (Bandung: Alfabeta, 2015), hlm.218-219.

10 Lexy. J. Moleong, Metode Penelitian Kualitatif, (Bandung: PT. Remaja Rosdakarya, 1994), hlm.330. 
Tabel 1. Daftar Subjek Penelitian

\begin{tabular}{cccccc}
\hline No. & Nama & Kasus & Pidana & $\begin{array}{c}\text { Tahun } \\
\text { keluar }\end{array}$ & $\begin{array}{c}\text { Pekerjaan setelah } \\
\text { menjadi napi }\end{array}$ \\
\hline 1. & NT & Pembunuhan & 20 Tahun & 2015 & Petani. \\
\hline 2. & UL & Pembacokan & 5 Tahun & 2014 & $\begin{array}{c}\text { Berjualan dan } \\
\text { membuka laundry }\end{array}$ \\
\hline 3. & SWS & Sabu-sabu & 4,4 Tahun & 2018 & $\begin{array}{c}\text { Melanjutkan } \\
\text { pendidikan. }\end{array}$ \\
\hline 4. & HC & Begal motor & 7,6 Tahun & 2017 & $\begin{array}{c}\text { Membuka bengkel } \\
\text { dan jual beli motor } \\
\text { dan mobil bekas. }\end{array}$ \\
\hline 5. & RF & $\begin{array}{c}\text { Pengedar } \\
\text { dan } \\
\text { konsumsi } \\
\text { ganja }\end{array}$ & 5,7 Tahun & 2019 & $\begin{array}{c}\text { Melanjutkan } \\
\text { pendidikan. }\end{array}$ \\
\hline & & & \\
\hline
\end{tabular}

\section{Temuan Penelitian}

Temuan peneliti di Kecamatan Klakah mengenai upaya penyesuaian diri yang dilakukan oleh para mantan narapidana di lingkungan masyarakat dengan judul Upaya Penyesuaian Diri Mantan Narapidana di Lingkungan Masyarakat Dalam Menanggapi Stigma Negatif di Kecamatan Klakah, Kabupaten Lumajang yaitu sebagai berikut:

Tabel 2. Hasil Temuan Penelitian

\begin{tabular}{cccc}
\hline Nama & $\begin{array}{c}\text { Situasi sesudah } \\
\text { menjadi mantan } \\
\text { narapadina }\end{array}$ & $\begin{array}{c}\text { Upaya merubah } \\
\text { Stigma Negatif }\end{array}$ & $\begin{array}{c}\text { Dampak setelah } \\
\text { menjadi mantan } \\
\text { narapidana }\end{array}$ \\
\hline Memiliki & $\begin{array}{c}\text { Membantu acara- } \\
\text { acara seperti } \\
\text { kebanggaan } \\
\text { tersendiri dan } \\
\text { menginginkan } \\
\text { pekerjaan yang } \\
\text { bisa memenuhi } \\
\text { kebutuhan sehari- } \\
\text { hari. }\end{array}$ & $\begin{array}{c}\text { berkumpul dengan } \\
\text { masyarakat sekitar } \\
\text { dan mengikuti } \\
\text { kegiatan pengajian } \\
\text { yang dilaksanakan } \\
\text { oleh masyarakat } \\
\text { tempat ia tinggal. }\end{array}$ & $\begin{array}{c}\text { Awal respon } \\
\text { masyarakat biasa } \\
\text { sajarhadap SNT } \\
\text { hanya saja } \\
\text { mengunjing dari } \\
\text { belakang. }\end{array}$ \\
\hline
\end{tabular}




\begin{tabular}{|c|c|c|c|}
\hline UL & $\begin{array}{c}\text { Menerapkan } \\
\text { keterampilan yang } \\
\text { diberikan semasa } \\
\text { masih di dalam } \\
\text { tahanan dan } \\
\text { mendapatkan } \\
\text { gunjingan dari } \\
\text { masyarakat } \\
\text { sekitar. }\end{array}$ & $\begin{array}{l}\text { Mengikuti pengajian- } \\
\text { pengajian yang di } \\
\text { selenggarakan oleh } \\
\text { masyarakat. }\end{array}$ & $\begin{array}{c}\text { Masyarakat yang } \\
\text { sering mengunjing } \\
\text { UL dan keluarga } \\
\text { dari belakang. Anak } \\
\text { dari UL } \\
\text { mendapatkan } \\
\text { diskriminasi dari } \\
\text { teman-temannya } \\
\text { hampir } 1 \text { tahun dia } \\
\text { berhenti untuk } \\
\text { sekolah. }\end{array}$ \\
\hline WSW & $\begin{array}{c}\text { Melanjutkan } \\
\text { pendidikan dan } \\
\text { memperbaiki diri. }\end{array}$ & $\begin{array}{c}\text { Menjaga kontak } \\
\text { dengan masyarakat } \\
\text { sekitar, bersikap } \\
\text { biasa aja dan } \\
\text { membuktikan } \\
\text { perubahan. }\end{array}$ & $\begin{array}{l}\text { Pandangan keluarga } \\
\text { menjadi anak yang } \\
\text { nakal, dikalangan } \\
\text { masyarakat menjadi } \\
\text { negatif, dan } \\
\text { kehilangan teman. }\end{array}$ \\
\hline $\mathrm{HC}$ & $\begin{array}{l}\text { Mendapatkan } \\
\text { gunjingan dari } \\
\text { tetangga dan } \\
\text { menerapkan skill } \\
\text { yang didapatkan } \\
\text { di LP. }\end{array}$ & $\begin{array}{l}\text { Membantu tetangga } \\
\text { yang mengalami } \\
\text { kesulitan dan } \\
\text { menjalin komunikasi } \\
\text { yang baik. }\end{array}$ & $\begin{array}{c}\text { HC sulit } \\
\text { mendapatkan } \\
\text { kepercayaan } \\
\text { kembali dari } \\
\text { masyarakat, } \\
\text { keluarga } \\
\text { mendapatkan } \\
\text { penilaian negatif } \\
\text { dan anak dari HC } \\
\text { mengalami } \\
\text { diskriminasi. } \\
\end{array}$ \\
\hline MRF & $\begin{array}{l}\text { Keluarga } \\
\text { mendapatkan } \\
\text { gunjingan. }\end{array}$ & $\begin{array}{l}\text { Mengikuti kegiatan } \\
\text { yang dilakukan } \\
\text { olehwarga sekitar. } \\
\text { Seperti gotong } \\
\text { royong, menjadi } \\
\text { imam di Musholla. }\end{array}$ & $\begin{array}{c}\text { Sulit mendapatkan } \\
\text { kepercayaan dari } \\
\text { orang tua, keluarga } \\
\text { dan masyarakat, } \\
\text { kehilangan teman } \\
\text { dan lebih } \\
\text { mendekatkan diri } \\
\text { kepada Allah. }\end{array}$ \\
\hline
\end{tabular}

Dari paparan tabel, dapat dipaparkan penjelasan sebagai berikut:

\section{Penyesuaian Diri Mantan Narapidana}

Mantan narapidana tentunya mempunyai kecemasan-kecemasan ketika kembali menjalani kehidupan di keluarga dan masyarakat tempat ia tinggal. Berdasarkan hasil wawancara yang peneliti lakukan ketika menanyakan tentang bagaimana perasaan subjek ketika kembali ke lingkungan masyarakat ternyata hasilnya berbeda-beda. SNT mengalami 
kondisi dimana ia merasa bangga akan apa yang SNT lakukan. UL mengalami rasa malu dan menyesal tetapi dia senang ketika kembali ke lingkungan rumahnya, karena di sekitar rumahnya bukan hanya dia yang menjadi seorang mantan narapidana. WSW merasa senang karena dia bisa kembali ke rumahnya. WSW merasa malu tetapi lebih merasa jera ketika menjalani kehidupan sehari-hari di Lembaga Permasyarakatan.

Penyesuaian kehidupan mantan narapidana meliputi suatu interaksi sosial dan aktivitas sosial. Interaksi sosial mantan narapidana meliputi sikap sosial dan komunikasi dengan keluarga dan masyarakat meliputi menjaga komunikasi dengan masyarakat, membantu masyarakat yang sedang mengalami kesulitan, ikut berkumpul dengan masyarakat. Sedangan untuk aktivitas sosial mantan narapidana meliputi mengikuti pengajian, membantu hajatan, mengikuti acara gotong royong. Keterampilan yang didapatkan di lapas atau Lembaga Pemasyarakatan juga tidak digunakan oleh SNT, sedangkan UL dan HC masih menggunakan keterampilan yang didapatkannya di Lembaga Pemasyarakatan. WSW dan MRF setelah keluar dari LP mereka melanjutkan pendidikannya untuk menjadikan dirinya lebih baik dan memperlihatkan bahwa dirinya juga bisa berubah dan lebih fokus terhadap pendidikannya.

\section{Upaya Penyesuaian Diri Mantan Narapidana}

Sebagai mantan napi yang telah melakukan perilaku yang dianggap menyimpang oleh masyarakat dan menjalani hukuman di penjara, tentu bukan hal yang mudah untuk berurusan dengan reaksi orang-orang terhadap apa yang telah mereka lakukan di masa lalu, karena ketika mantan narapidana meninggalkan penjara, mereka harus siap untuk dapat beradaptasi kembali ke masyarakat dan menghadapi segala tekanan dari masyarakat di lingkungan mereka. Mantan tahanan yang meninggalkan penjara atau pusat penahanan perlu meyiapkan aspek psikologis, fisik, sosial, ekonomi dan agama mereka. Biasanya setelah keluar mantan narapidana akan merasa takut menjumpai perasaan yang menyiksa diri seperti kesepian, perasaan tidak berguna, disepelekan dan perasaan tidak mampu lainnya. Mantan narapidana juga ingin diperhatikan, disayang, dan dicukupi kebutuhannya. Mantan narapidana tidak mengharapkan jika mendapat suatu cacian, dicemooh dan tetap menyandang status sebagai orang yang tidak baik karena pernah melanggar suatu norma hukum tertentu di dalam lingkungan masyarakat tempat mereka tinggal. 
Mantan narapidana juga makhluk sosial, kapanpun dan dimanapun juga membutuhkan orang lain. Kebutuhan bersosialisasi merupakan kebutuhan dasar manusia setelah kebutuhan fisiologis dan kebutuhan rasa aman. Kehangatan dari lingkungan di sekitar lingkungannya dapat mengurangi rasa tidak nyaman yang dialaminya. Mantan narapidana juga mempunyai kebutuhan seperti pada manusia pada umumnya. Mantan narapidana juga sangat membutuhkan pekerjaan untuk dapat memenuhi kebutuhan hidupnya, menemukan pasangan hidupnya, untuk meneruskan keturunannya dan kebutuhan lain-lainnya. Religiusitas yang dimiliki oleh seorang mantan narapidana sangat dibutuhkan agar mantan narapidana tidak kembali melakukan kesalahan atau kejahatan yang sama yang dapat membuat mereka mendekam di jeruji besi. Mantan narapidana bukan manusia yang penuh dengan kesalahan-kesalahan tetapi juga mempunyai kesempatan kedua untuk memperbaiki diri dan meningkatkan kualitas dalam hidupnya. Persepsi publik bahwa seorang mantan narapidana masih memiliki kecenderungan kuat untuk menjadi residivis atau seseorang yang berulang kali melakukan kejahatan, dalam arti kambuh seperti penyakit. Hal ini akan membuat mantan narapidana tidak bisa mendapatkan hak asasinya kembali di komunitasnya untuk didiskriminasi dari lingkungan sendiri.

Reaksi yang ditunjukkan oleh mantan narapidana ketika dihadapkan dengan stigma yang muncul dari masyarakat tentu berbeda. Misalnya, SNT yang mengatakan ketika seseorang tahu bahwa dia adalah mantan napi hanya merespons dengan santai. Reaksi SNT tidak pernah menutupi statusnya sebagai mantan narapidana dari masyarakat. Reaksi yang ditunjukkan oleh SNT adalah karena fakta bahwa di daerah tempat tinggal SNT, mayoritas memang memegang status mantan narapidana sehingga jika apa yang kita miliki di ganggu oleh orang lain, maka harus membalasnya dengan hal yang setimpah, justru ketika kita tidak membalas perbuatannya maka dianggap aneh oleh masyarakat sekitar tempat tinggalnya.

\section{Bentuk Perilaku Mantan Narapidana Sebagai Upaya Dalam Mengubah Stigma Negatif Di Lingkungan Masyarakat}

Bentuk interaksi sosial yang dilakukan oleh seorang mantan narapidana setelah keluar dari LP sebagai upaya untuk mengubah stigma negatif yang ada di dalam lingkungan masyarakat yaitu yang pertama perilaku nilai. Dengan menunjukkan sikap ramah, penunjukan sikap bersahabat dilakukan oleh mantan narapidana dengan memberikan teguran 
atau salam saat bertemu dengan tetangga atau menyapa saat bertemu dengan tetangga dan bersikap lembut, ramah dan menghormati tetangga. Seperti informan UL, ia terus menunjukkan perilaku positif meskipun ia merasa sering dikucilkan oleh masyarakat. Dia terus menunjukkan sikap ramah terhadap masyarakat.

Kedua, perilaku rasional. Dengan membantu tetangga yang mengalami kesulitan, mantan narapidana selalu memberikan bantuan kepada tetangga yang mengalami kesulitan atau masalah. Ini adalah perwujudan dari perawatan mantan narapidana dengan tetangga yang dianggap mantan narapidana sebagai kerabat dekat mereka ketika mengalami kesulitan atau bencana. Ini adalah bentuk perilaku yang dilakukan oleh informan HC. Dia adalah mantan narapidana yang selalu melakukan itu. Setiap kali tetangga membutuhkan bantuan, dia tidak ragu untuk membantu.

Ketiga, perilaku praktis. Membangun komunikasi yang baik dengan keluarga dan tetangga, mengobrol bersama, berbagi, dan mengeluh adalah cara yang dilakukan mantan narapidana dalam kehidupan sehari-hari dengan keluarga dan tetangga. Dengan menjalin komunikasi yang baik, mantan narapidana merasa mereka memahami situasi yang dialami oleh mantan narapidana. Seorang mantan narapidana harus berpartisipasi aktif dalam setiap kegiatan komunitas di mana dia tinggal. Contoh informan WSW dengan kasus mengkonsumsi sabu. WSW mengaku mampu mengubah stigma negatif dengan menjaga komunikasi yang baik. SNT, ia adalah mantan narapidana dengan kasus pembunuhan yang sekarang dikenal oleh masyarakat sekitarnya tetapi setiap kali ada kegiatan sosial ia selalu aktif, misalnya menghadiri resital, membantu di pesta pernikahan.

Keempat, perilaku emosional. Dengan merespons stigma negatif dengan bertindak biasa-biasa saja, merespons pandangan tetangga dengan cara biasa, jahil, tetap percaya diri, sadar akan kesalahan dan menunjukkannya dengan sikap positif dari setiap kegiatan yang dilakukan. Seperti informan UL yang selalu ditanggapi secara negatif oleh masyarakat, ia sangat sulit untuk mendapatkan kepercayaan dari masyarakat tetapi ia selalu menunjukkan hal-hal positif kepada semua orang, terutama tetangga di lingkungannya. Berpartisipasi aktif dalam kegiatan yang diselenggarakan oleh masyarakat tempat mereka tinggal, seorang mantan narapidana mencoba berinteraksi dengan bergaul dan membaur di dalam lingkungan masyarakat. Cara yang dilakukan dalam upaya agar bisa diterima kembali 
adalah dengan ikut berpartisipasi dalam setiap kegiatan yang dilakukan oleh masyarakat sekitar. Kegiatan yang dilakukan seperti, mengikuti pengajian muslimatan.

\section{Bentuk Perubahan Yang Terjadi Pada Mantan Narapidana}

Bentuk-bentuk perubahan yang terjadi pada mantan narapidana setelah meninggalkan Lembaga Permasyarakatan yaitu, mantan narapidana memiliki perubahan ke arah yang lebih positif. Perubahan positif yang dilakukan mantan narapidana setelah keluar dari Lembaga Pemasyarakatan dapat berupa hal-hal berikut, pertmana bertambahnya iman dan ketakwaan. Banyak mendapatkan ilmu agama ketika program kerohanian di dalam Lembaga Pemasyarakatan membuat ada suatu perbedaan dalam hal spiritual yang terdapat dalam diri seorang mantan narapidana. Selain menyadari akan dosa yang diperbuatnya di masa lalu, setelah keluar dari Lembaga Pemasyarakatan para mantan narapidana terlihat lebih mantap dalam keagamaannya seperti rajin sholat berjamaah di masjid, mengikuti acara-acara pengajian yang dilaksanakan di lingkungan masyarakat tempat ia tinggal.

Kedua, lebih peka dan aktif dalam kegiatan kemasyarakatan. Sikap yang cuek merupakan sikap yang dulunya dimiliki oleh mantan narapidana. Namun, setelah mantan narapidana keluar dari Lembaga Pemasyarakatan, mantan narapidana menunjukan perubahan dalam dirinya dengan aktif dalam kegiatan kemasyarakatan, seperti selalu menghadiri acara pernikahan, syukuran, tahlilan dan gotong royong di lingkungan sekitar. Perubahan tersebut diharapkan mampu memperlihatkan sisi positif mantan narapidana yang ingin berubah dan bergaul dengan masyarakat sehingga diterima dan diakui keberadaannya sebagai bagian dari warga setempat.

Ketiga, menjauhi pergaulan dan kebiasaan di masa lalu. Lingkungan merupakan agen sosialisasi yang sangat erat kaitannya dalam pembentukan kepribadian seseorang. Mantan narapidana yang benarbenar menyadari dosa dan kejahatannya di masa lalu. Ia akan memilih untuk pergi meninggalkan masa lalunya yang dianggap suram. Mantan narapidana masih terus bergaul dengan rekan lamanya, hal tersebut memungkinkan mantan narapidana kembali ke jalan yang salah. Seharusnya yang dilakukan mantan narapidana ialah membuang masa lalu dan mencoba beradaptasi ulang dengan rekan masyarakat tempat tinggal yang 
memiliki energi untuk menjadikan mantan narapidana berperilaku positif pula.

Berbagai bentuk perubahan positif mantan narapidana tersebut dapat dikatakan sebagai buah hasil dari pembinaan yang dilakukan oleh Lembaga Pemasyarakatan ketika masih mendapatkan hukuman pidana. Perubahan didukung oleh proses pembinaan dari kepolisian juga didukung oleh dukungan dari berbagai pihak seperti keluarga dan masyarakat tempat tinggal mantan narapidana. Oleh karena itu, diharapkan masuknya mantan narapidana ke dalam Lembaga Pemasyarakatan sebagai upaya agar mantan narapidana mampu bisa berubah untuk menjadi individu yang lebih positif dalam menjalani kehidupannya, jera dan memperbaiki diri dengan berbagai program yang ada di dalam Lembaga Pemasyarakatan. Upaya-upaya tersebut dapat berupa berbagai kegiatan pengajian, salat berjamaah, siraman rohani dan kegiatan keagamaan lainnya yang ada di dalam LP.

\section{Dampak Positif Yang Diterima Mantan Narapidana}

Dampak yang terjadi pada mantan narapidana setelah melakukan adaptasi di dalam lingkungan masyarakat berdasarkan temuan penelitian, sebagai berikut:

Pertama, perubahan respon dari keluarga. Keluarga yang awalnya merasa sedih, kecewa dan marah ketika melihat kasus kejahatan yang dilakukan oleh mantan narapidana perlahan berubah seiring proses adaptasi yang dilakukan individu dalam upaya mengubah stigma negatif dalam dirinya. Hingga saat ini seluruh pihak keluarga merasa sangat bahagia ketika melihat perubahan dan penerimaan diri yang dilakukan oleh mantan narapidana dalam kehidupan sehari-hari. Bahkan beberapa keluarga tidak menyangka perubahan dan proses adaptasi anggota keluarganya di tengah masyarakat hingga saat ini.

Kedua, hilangnya stigma negatif dari tetangga. Setelah mantan narapidana melakukan proses adaptasi dengan melakukan interaksi dan menjalin hubungan yang baik dengan tetangga baik melalui tegur sapa, sopan santun, serta tolong menolong, terlibatnya mantan narapidana dalam kegiatan kemasyarakatan dan penunjukan perubahan diri mengakibatkan stigma negatif di dalam masyarakat yang awalnya kuat perlahan mulai hilang. Hal tersebut karena masyarakat juga merupakan agen yang mampu menilai dan mengawasi individu yang berada di 
dalam bagian lingkungannya. Oleh sebab itu, dampak yang diberikan kepada mantan narapidana sebagai hasil dari proses adaptasi adalah penerimaan dirinya di tengah masyarakat dan dipercaya sebagai orang yang ingin berubah dari masa lalu.

Ketiga, mantan narapidana memiliki peran di dalam masyarakat. Mantan narapidana yang awalnya merupakan orang yang dianggap buruk di dalam masyarakat saat ini setelah beradaptasi memiliki perubahan. Perubahan tersebut berupa mantan narapidana sebagai tokoh masyarakat yang dituakan di daerah setempat. Mereka dianggap sebagai orang yang pernah makan asam garam kehidupan dan telah terlihat perubahannya dalam kehidupan. Perubahan yang ditunjukkan mereka membuat masyarakat percaya jika mantan narapidana merupakan orang yang mampu memberikan nasehat dan membantu mencarikan jalan keluar. Beberapa peran tersebut terlihat ketika saat ini mantan narapidana sering membawakan kata sambutan dalam acara pernikahan dan sering menjadi ketua dalam kegiatan kemasyarakatan seperti pernikahan dan acara lainnya. Selajutnya peran sebagai pengurus masjid juga merupakan bentuk keberhasilan mantan narapidana yang dipercayai oleh masyarakat dalam mengemban tugas dan tanggungjawab yang tidak semua orang mampu melakukannya. Menjadi pengurus masjid dan tokoh masyarakat merupakan salah satu bentuk keberhasilan atas dampak mantan narapidana dalam beradaptasi di tengah masyarakat.

Keempat, memiliki keleluasaan untuk hidup bermasyarakat. Masa lalu yang suram dan kesalahan dalam melanggar norma di masyarakat menjadikan mantan narapidana yang saat itu hidup tercengkam dengan rasa takut dan was-was ketika melakukan sesuatu hal di luar rumah. Namun, saat ini mantan narapidana mengalami perubahan dan melakukan adaptasi di tengah masyarakat. Hasil yang mereka dapatkan ditunjukkan dengan adanya bentuk keleluasaan dalam bergaul. Hal tersebut karena mantan narapidana sudah tidak merasa bersalah sehingga tidak ada sekat yang membatasi mantan narapidana untuk hidup bebas dan leluasa di lingkungan masyarakat.

Kelima, memiliki pekerjaan yang tetap. Memiliki pekerjaan sama halnya dengan pemberian kepercayaan dari masyarakat kepada mantan narapidana yang dianggap memiliki prilaku yang baik setelah melakukan proses adaptasi. 


\section{Dampak Negatif Yang Diterima Mantan Narapidana}

Masalah sosial muncul dari keadaan ketidakseimbangan antara komunitas dan mantan narapidana, yang pada dasarnya dapat mempengaruhi tahanan setelah dibebaskan dari penjara dan kembali ke lingkungan masyarakat. Masyarakat menyoroti banyak dari perspektif negatif semua bentuk perilaku dan kegiatan sehari-hari tahanan yang bebas dari penjara, sehingga mereka merasa dikucilkan atau tersisihkan dari lingkungan masyarakat. Dampak negatif yang harus diterima oleh mantan narapidana berdasarkan temuan penelitian, sebagai berikut yang pertama mendapatkan gunjingan dari tetangga. Berdasarkan informasi yang didapatkan oleh peneliti dalam meneliti para subjek (mantan narapidana) yaitu subjek SNT, UL, WSW, HC, dan MRF mendapatkan gunjingan dari tetangga tempat para subjek tinggal. Tidak hanya mengunjing subjek saja, tetapi keluarga subjek yang tidak tahu apa-apa juga merasakan atas gunjingan tetangga. Selama subjek mendekam di Lembaga Permasyarakatan, tetangga membicarakan kelakuan subjek. Ketika subjek sudah keluar dari Lembaga Permasyarakatan, subjek juga mengalami gunjingan tetangga. Namun, gunjingan tersebut akan hilang ketika subjek mulai menunjukkan perubahan yang lebih baik lagi.

Kedua, diskriminasi terhadap anak. Berdasarkan informasi yang diberikan oleh UL, terdapat diskriminasi yang dilakukan oleh masyarakat atau teman-teman sekolah anaknya ketika ia berada di dalam Lembaga Permasyarakatan untuk mempertanggung jawabkan perbuatannya.

\section{Analisis Temuan Penelitian dengan Teori Looking Glass Self dari Charles Horton Cooley}

Cooley menjelaskan bahwa konsep cermin diri (Looking Glass Self) sebagai suatu imajinasi yang agak defenitif mengenai bagaimana diri seseorang yakni melakukan suatu gagasan yang ia sediakan kemudian muncul dalam pemikiran tertentu dan semacam perasaan diri seseorang yang ditentukan oleh suatu sikap terhadap hubungan dari pikiran dan perasaan dengan pikiran orang lain ${ }^{11}$. Dalam teori ini, kita tampaknya hlm.99.

11 Jalaludin Rakhmat, Psikologi Komunikasi, (Bandung: Rosda Karya, 2007), 
meletakkan cermin di depan kita dan membayangkan bagaimana orang lain akan menilai penampilan kita atau kemampuan kita untuk melihat diri kita sendiri dalam refleksi atau pandangan orang lain ${ }^{12}$. Konsep diri seseorang juga dipengaruhi oleh apa yang diyakini oleh individu, yang dipikirkan orang tentang diri mereka sendiri.

Pertumbuhan dan perkembangan perasaan diri (self feeling) merupakan hasil dari proses komunikasi interpersonal dalam suatu lingkungan sosial berdasarkan interaksi dan persepsi orang lain yang timbul dari hasil proses interaksi dan hasil pembentukan sifat sosial melalui perasaan diri (self feeling). Terdapat tiga komponen dalam Looking Glass Self (cermin diri) menurut Cooley dalam (Ritzer dan Goodman, yaitu: ${ }^{13}$

Komponen pertama, kita membayangkan bagaimana ia tampak dimata orang lain. Sejak stigma sebagai "imam musholla, menjaga komunikasi dengan masyarakat (membantu teguran dan sapaan), membantu masyarakat yang sedang mengalami kesulitan, mengikuti acara-acara yang sedang dilakukan di lingkungan masyarakat (gotong royong, membantu acara pernikahan, mengikuti pengajian), dan berkumpul dengan masyarakat" itu dilekatkan kepada mantan narapidana, seseorang mantan narapidana akan mengganggap bahwa masyarakat menilainya sebagai mantan narapidana yang berperan sebagai imam musholla, menjaga komunikasi dengan masyarakat (membantu teguran dan sapaan), membantu masyarakat yang sedang mengalami kesulitan, mengikuti acara-acara yang sedang dilakukan di lingkungan masyarakat (gotong royong, membantu acara pernikahan, mengikuti pengajian), dan berkumpul dengan masyarakat. Adanya cermin diri mungkin akan diterima oleh individu tersebut dan berusaha untuk menjadi sebagaimana stigma yang sudah dilekatkan pada dirinya.

Komponen kedua, kita membayangkan bagaimana seharusnya penilaian mereka terhadap tampilan ini. Reaksi selanjutnya seorang mantan narapidana akan berusaha menjalani sebagai seorang mantan narapidana yang berperan sebagai imam musholla, menjaga komunikasi dengan masyarakat (membantu teguran dan sapaan), membantu masyarakat yang sedang mengalami kesulitan, mengikuti acara-acara yang

12 E. Grifin, In A First look at Communication Theory (p.Eight Edition), (Amerika: McGrew Hill, 2012), hlm.60. hlm.397.

13 Ritzer dan Goodman, Teori Sosiologi Modern, (Jakarta: Kencana, 2007), 
sedang dilakukan di lingkungan masyarakat (gotong royong, membantu acara pernikahan, mengikuti pengajian), dan berkumpul dengan masyarakat tempat ia tinggal, ia akan menginterpretasikan anggapan masyarakat. Pertama, menjadi imam musholla yang memiliki akhlak yang baik dan menjadi contoh kaum muda untuk lebih menjadi baik. Kedua, menjaga komunikasi dengan cara menunjukkan sikap ramah, penunjukan sikap ramah yang dilakukan oleh mantan narapidana dengan memberikan teguran atau sapaan ketika bertemu dengan tetangga dan bersikap lembut, baik dan menghargai tetangga. Ketiga, dengan membantu tetangga yang sedang mengalami kesulitan, mantan narapidana selalu memberikan suatu pertolongan kepada tetangga yang sedang mengalami suatu kesulitan atau masalah. Hal tersebut wujud dari kepedulian mantan narapidana kepada tetangga. Keempat, menjalin komunikasi yang baik dengan keluarga dan tetangga, mengobrol bersama dan saling berbagi keluh kesah. Kelima, berpartisipasi aktif dalam kegiatan yang diselenggarakan oleh masyarakat tempat ia tinggal, mantan narapidana mencoba berinteraksi dengan cara bergaul dan membaur di dalam lingkungan msyarakat dengan cara mengikuti kegiatan gotong royong, mengikuti pengajian, membantu di hajatan yang diselenggarakan di lingkungan masyarakat. Hal ini akan menimbulkan perasaan diri seorang mantan narapidana, bahwa dirinya diberi keyakinan dan mampu dipercaya oleh masyarakat.

Komponen ketiga, kita mengembangkan perasaan diri sebagai akibat dari bayangan kita terhadap penilaian orang lain. Seorang mantan narapidana yang diberi stigma sebagai imam musholla akan merasa bahwa orang di sekelilingnya telah mengetahui perbuatanya. Salah satu proses tersebut akan menjelaskan tentang reaksi seorang mantan narapidana setelah mengetahui reaksi orang lain terhadap dirinya. Sehingga akan menumbuhkan perasaan dan ide mengenai dirinya sendiri yaitu bagaimana ia akan menginterpretasikan reaksi masyarakat terhadap dirinya dalam kehidupan sosial, apakah refleksi dari reaksi masyarakat terhadap mantan narapidana mengarah pada suatu konsep diri yang membentuk peran dan sikap yang positif atau negatif. Namun dalam penelitian ini disimpulkan bahwa cermin diri seorang mantan narapidana mengarah kepada hal yang positif karena berbeda pada umumnya masyarakat menilai seorang mantan narapidana. Mantan narapidana masih dianggap sebagai penjahat dan keberadaan mencemaskan masyarakat. Akan tetapi di Kecamatan 
Klakah mantan narapidana diterima dengan baik dan mampu hidup berdampingan dengan harmonis.

\section{Analisa Temuan Peneliti dengan Teori Stigma dari Erving Goffman}

Setiap orang memiliki pemaknaan yang berbeda terhadap suatu hal, baik itu yang ada dalam diri sendiri atau orang lain. Seperti yang diungkapkan oleh Erving Goffman dalam teorinya mengenai diri (self), yaitu bagaimana seseorang memaknai dirinya sendiri sebelum mendengar tentang dirinya dari orang lain. Seseorang akan bisa memaknai dirinya dirinya sendiri jika seseorang melihat dirinya sebagai objek. Dikucilkan dan menjadi bahan pembicaraan oleh masyarakat sudahlah menjadi hal yang biasa bagi seorang mantan narapidana, setelah bebas dari lembaga pemasyarakatan namun itulah kenyataan yang harus diterima dan dijalani oleh seorang mantan narapidana. Setelah bebas dari lembaga pemasyarakatan seorang mantan narapidana harus mempersiapkan diri dan mental untuk berhadapan dengan orang lain, mengingat statusnya yang sebagai mantan narapidana yang tidak mudah diterima oleh masyarakat.

Goffman mendefinisikan stigma sebagai situasi individu yang terdiskualisasi dari penerimaan sosial yang utuh atau situasi yang tidak menerima penerimaan utuh ${ }^{14}$. Goffman menggunakan konsep stigma untuk menggambarkan suatu proses yang dimana orang-orang tertantu secara moral dianggap tidak berharga atau dengan kata lain stigma merupakan sikap, perlakuan atau perilaku masyarakat yang memandang perilaku tertentu sebagai hal yang buruk sebagai orang yang secara moral tidak berharga. Apa yang dapat seseorang lakukan dan apa yang seharusnya untuk ia lakukan akan membentuk identitas pada individu. Mantan narapidana adalah seseorang yang rawan menerima stigmatisasi dan perilaku diskriminatif dari masyarakat. Dari teori yang berhasil ditemukan Goffman bisa ditarik kesimpulan bahwa mereka sama-sama fokus terhadap proses interaksi yang dilakukan oleh manusia. Dimana akan ada subyek yang melakukan interaksi dan ada pihak lain yang memberikan respon dari interaksi yang dilakukan.

\section{Simpulan}

${ }^{14}$ Erving Goffman, Stigma: Notes On The Management Of Spoiled Identity, (New York: Simon \& Schuster Inc, 1963), hlm.3. 
Memang sulit bagi individu yang berstatus sebagai mantan narapidana untuk dapat kembali bergaul dengan masyarakat, sehingga mereka dapat mengubah pandangan masyarakat tentang diri mereka sendiri. Mantan narapidana harus menunjukkan perilaku ramah dengan saling tegur sapa, menjadi lebih baik, sopan, membantu tetangga yang mengalami kesulitan, menjalin komunikasi yang baik dengan keluarga dan tetangga, secara aktif berpartisipasi dalam kegiatan yang dilakukan di masyarakat seperti berpartisipasi dalam kegiatan gotong royong, ikut serta dalam acara pengajian yang diadakan oleh penduduk setempat dan acara lainnya. Tanggapi stigma negatif dengan bersikap sopan dengan percaya diri dan menunjukan perubahan sikap yang lebih baik kepada masyarakat sekitar. Untuk memenuhi kebutuhan hidup seharihari, mantan narapidana harus bekerja untuk memenuhi semua kebutuhan mereka sehari-hari. Sulit bagi seseorang yang dianggap mantan narapidana untuk bisa mendapatkan kepercayaan penuh dari masyarakat sekitar setelah tindakan kriminal yang pernah mereka lakukan, sehingga sulit bagi mantan narapidana untuk mendapatkan pekerjaan.

Respon masyarakat kepada mantan narapidana juga berbeda-beda. Beberapa orang menganggap keberadaan mantan narapidana sebagai hal yang normal karena mayoritas masyarakat di sekitar narapidana tidak sulit untuk dapat didaur ulang dengan masyarakat. Mantan narapidana mengartikan status tahanan adalah bagian dari perjalanan hidup yang harus dilalui dan banyak pelajaran bisa diambil saat masih berstatus tahanan. Upaya penyesuaian diri yang digunakan oleh mantan narapidana untuk diterima kembali di masyarakat cukup beragam. Mantan narapidana selalu mengambil tindakan positif sehingga orang-orang percaya bahwa mantan narapidana memang berubah. Tindakan positif yang diambil oleh mantan narapidana termasuk aktif di masyarakat dengan berpartisipasi jika ada kegiatan seperti kerja bakti atau gotong royong, pengajian, membantu tetangga disekitar yang mempunyai hajad atau acara, menjadi imam di Musholla, menjaga komunikasi dengan tetangga.

\section{Saran}

Penulis menyadari bahwa dalam penelitian ini tidak luput dari kesempurnaan dalam makna intrinsik, karena masih ada ruang untuk mengeksplorasi lebih lanjut tentang masalah tersebut upaya penyesuaian diri dari mantan narapidana di lingkungan masyarakat. Hasil penelitian ini juga bisa menjadi tambahan referensi bagi beberapa pihak yang terkait: 
Pertama, masyarakat, ketidakpedulian masyarakat, ketidaktahuan dan tidak menerima narapidana yang telah dibebaskan dari tahanan harus segera dihapus karena mereka dapat memiliki dampak yang lebih besar pada mantan narapidana. Masyarakat harus secara bertahap dapat menerima kehadiran mereka dan merangkul mereka dalam berbagai kegiatan desa untuk mengurangi inferioritas yang dialami oleh mantan narapidana.

Kedua, tahanan yang telah dibebaskan dari Pusat Penahanan harus dapat menginspirasi diri mereka sendiri dengan aspirasi yang membangun untuk kembali hidup dalam komunitas lagi. Perasaan malu, inferioritas kompleks (inferioritas terhadap lingkungan), kekecewaan harus segera dihilangkan dan dengan semangat baru, dengan menunjukkan sikap yang baik dan tidak mengulangi kesalahan masa lalu sehingga orang dapat menerima kehadiran mereka sebagai masyarakat yang baik. Percayalah bahwa mantan narapidana juga memiliki hak yang sama dalam hidup, yang merupakan peluang untuk meningkat. Masih banyak cara untuk menjadi manusia yang lebih baik dengan niat, kemauan, ketulusan, dan upaya yang tepat untuk membangun konsep diri yang positif sebagai bekal dalam memberi makna pada setiap langkah kehidupan selanjutnya.

Ketiga, orang tua, terutama dari mantan napi, harus bisa memberikan motivasi, semangat dan pandangan yang positif kepada anak-anak mereka sehingga mereka ingin menjalani kehidupan mereka berikutnya di luar tahanan.

Keempat, pemerintah bersama-sama dengan petugas aparat untuk memberikan kesempatan atau bagi tahanan yang telah dibebaskan dari penjara untuk bekerja untuk memenuhi kebutuhan ekonomi, serta menghilangkan asumsi buruk tentang tahanan sehingga mereka dapat bekerja dengan baik di lembaga pemerintah atau swasta. Kelima, perguruan tinggi, terutama siswa yang belajar di luar daerah ketika kembali ke desa dapat memberikan penyuluhan di desa dengan tema bahwa mendiskriminasi mantan narapidana bukanlah perbuatan baik.

\section{DAFTAR PUSTAKA}

Arikunto, Suharsimi. Prosedur Penelitian Suatu Pendekatan Praktik. Jakarta: PT Rineka Cipta. 2010. 
Gunawan, Imam. Metode Penelitian Kualitatif: Teori dan Pratik. Jakarta:

Bumi Aksara, 2013.

Goffman, Erving. Stigma: Notes On The Management Of Spoiled Identity. New York: Simon \& Schuster Inc, 1963.

Grifin, E. In A First look at Communication Theory (p.Eight Edition). Amerika: McGrew Hill. 2012.

Iskandar, Abraham Barkah. Resiliensi Mantan Narapidana Terhadap Penolakan Lingkungan. Skripsi. Program Studi Psikologi Fakultas Psikologi Universitas Sanata Dharma Yogyakarta. 2017.

Moleong, Lexy. J. Metode Penelitian Kualitatif. Bandung: PT. Remaja Rosdakarya. 1994.

Rakhmat, Jalaludin. Psikologi Komunikasi. Bandung: Rosda Karya. 2007.

Ritzer, G dan Goodman. Teori Sosiologi Modern. Jakarta: Kencana, 2007.

S., Nasution. Metode Penelitian Naturalistik Kualitatif. Bandung: PT Tarsito. 1996.

Strauss, Anselm \& Imam Muttaqien. Dasar-dasar Penelitian Kualitatif. Yogyakarta: Pustaka Pelajar. 2007.

Sugiyono. Metode Penelitian Kuantitatif Kualitatif dan R\&D. Bandung: Alfabeta, 2015.

Sukardi. Penelitian Subjek Penelitian. Yogyakarta: Lembaga Penelitian IKIP Yogyakarta. 1995

Yusuf, A Muri. Metode Penelitian: Kuantitatif, Kualitatif, dan Penelitian Gabungan. Jakarta: Prenamedia Group, 2014. 